\title{
Analisis Indeks Pembangunan Manusia (IPM) Kabupaten/Kota di Provinsi Maluku Utara Menggunakan Indeks Geary $C$ Berdasarkan Resampling Estimasi Densitas Kernel
}

\author{
http://dx.doi.org/10.28932/jutisi.v5i1.914
}

\author{
Fetriks Theo Sarita ${ }^{1}$, Adi Setiawan ${ }^{2}$, Hanna Arini Parhusip ${ }^{3}$ \\ ${ }^{123}$ Jurusan Matematika Fakultas Sains dan Matematika,Universitas Kristen Satya Wacana \\ Jl. Diponegoro52-60 Salatiga 50711 \\ 1662015038 estudent. uksw.edu \\ ${ }^{2}$ adi.setiawanestaff.uksw.edu \\ 3hanna.ariniestaff.uksw.edu
}

\begin{abstract}
In this study, it is discussed the Regency/City Human Development Index (HDI) in North Maluku Province to determine the spatial influence of HDI. The data used are Regency/City HDI in North Maluku Province from 2013 to 2017. Furthermore, spatial autocorrelation test with Geary $C$ index is used based on resampling by using Estimated Kernel Density. The test is done to determine whether the Regency/City HDI affects the neighboring Regency/City HDI. Based on the results of optimal bandwidth usage $\left(h_{\text {opt }}\right)$ with a repetition of 10000 times it is obtained p-value $0.0318,0.0272$, $0.0282,0.0262$ and 0.0258 , respectively from 2013 to 2017 . Thus, there is a spatial between Regencies/Cities in North Maluku Province from 2013 to 2017. In other words, if the HDI in a Regency/City is high then the neighbouring Regency/City HDI tends to be high, and vice versa.
\end{abstract}

Keywords- Geary's C, Kernel Density Estimation, Spatial Autocorrelation.

\section{Pendahuluan}

Kuantifikasi untuk berbagai aktivitas pembangunan di Indonesia seringkali dinyatakan dalam bentuk indeks seperti Indeks Pembangunan Manusia (IPM), Indeks Kebahagiaan, Indeks Pembangunan Gender (IPG), Indeks Harga Konsumen (IHK), Indeks Gini (Gini Ratio), dan masih banyak lagi. Hal ini dibuat untuk memberikan ilustrasi keberhasilan suatu program/perencanaan pada periode tertentu di suatu pemerintahan. Salah satu indeks yang dipelajari pada penelitian ini adalah Indeks Pembangunan Manusia (IPM).

Penelitian tentang Indeks Pembangunan Manusia (IPM) menggunakan autokorelasi spasial pernah dilakukan oleh Weku dkk (2012) [1] dan Nisa (2017) [2]. Sejak tahun 2014 Indonesia telah menerapkan perhitungan IPM metode baru. Akan tetapi untuk menjaga kesinambungan perhitungan, IPM metode baru dihitung dari tahun 2010 sampai sekarang. IPM metode baru terdiri dari 3 dimensi yaitu dimensi umur panjang dan hidup sehat, dimensi pengetahuan dan dimensi standar hidup layak [3]. Dimensi umur panjang dan hidup sehat diukur melalui indeks kesehatan dengan indikator yaitu angka harapan hidup saat lahir (AHH), dimensi pengetahuan diukur melalui indeks pendidikan dengan indikator yaitu harapan lama sekolah (HLS) dan rata-rata lama sekolah (RLS) dan dimensi standar hidup layak diukur melalui indeks pengeluaran dengan indikator yaitu pengerluaran per kapita.

Saat ini masalah pemerataan pembangunan merupakan salah satu isu pemerintah dalam berhasil tidaknya melakukan pembangunan bagi masyarakat Indonesia. Salah satu perhatian pemerintah adalah masalah kesenjangan pembangunan manusia antar Kabupaten/Kota di suatu Provinsi yang relatif tinggi. Untuk itu, pada penelitian ini dilakukan analisa IPM untuk menentukan apakah IPM Kabupaten/Kota yang bertetangga saling mempengaruhi atau tidak.

Metode yang digunakan adalah autokorelasi spasial menggunakan indeks Geary $C$ berdasarkan Resampling Estimasi Densitas Kernel. Tes autokorelasi spasial digunakan karena dapat mengidentifikasi nilai-nilai yang diamati dari variabel pada satu lokasi bergantung atau tidak bergantung pada nilai-nilai variabel di lokasi yang berdekatan/bertetangga [4].

Dengan mengetahui ada atau tidaknya autokorelasi spasial (spatial autocorrelation) pada IPM antar Kabupaten/Kota di Provinsi Maluku Utara, diharapkan kesimpulan tersebut dapat membantu pemerintah, baik pemerintah Provinsi ataupun pemerintah Kabupaten/Kota dalam merancang program untuk meningkatkan 
pembangunan manusia dan mengurangi kesenjangan pembangunan manusia.

\section{DASAR TEORI}

\section{A. Data Spasial}

Data spasial adalah data yang berkaitan dengan lokasi berdasarkan geografis yang terdiri dari lintang-bujur dan wilayah [5]. Data spasial digunakan dalam Sistem Informasi Geografis (GIS) untuk perencanaan pembangunan dan pengelolaan sumber daya alam yang berkelanjutan, salah satu contoh pemanfaatan data spasial yaitu pembuatan peta suatu wilayah.

\section{B. Matriks Pembobot Spasial}

Matriks pembobot spasial (spatial weight matrix) digunakan untuk mengetahui kedekatan (contiguity) antar suatu wilayah/lokasi. Matriks pembobot spasial dibedakan menjadi tiga [6].

1. Rook Contiguity adalah wilayah/lokasi dikatakan bertetangga jika lokasi-lokasi tersebut bersentuhan sisi (maksimal 4 tetangga).

2. Bishop Contiguity adalah wilayah/lokasi dikatakan bertetangga jika lokasi-lokasi tersebut bersentuhan sudut (maksimal 4 tetangga).

3. Queen Contiguity adalah wilayah/lokasi dikatakan bertetangga jika lokasi-lokasi tersebut bersentuhan sisi atau sudut (maksimal 8 tetangga).

Tiga jenis matriks pembobot spasial diilustrasikan seperti pada Gambar 1.

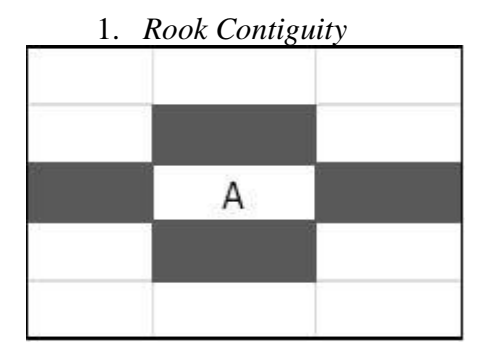

2. Bishop Contiguity

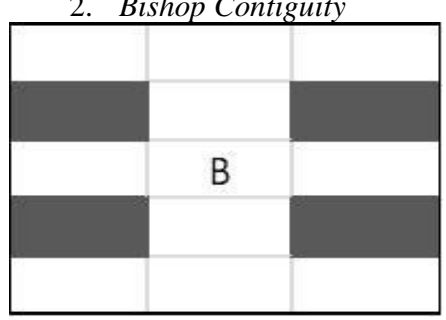

3. Queen Contiguity

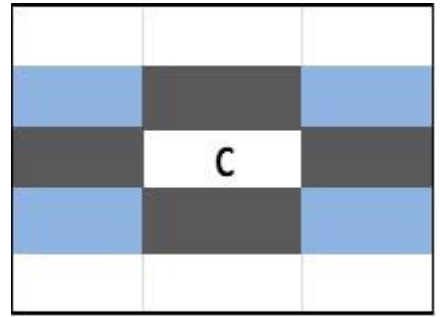

Gambar 1. Ilustrasi Matriks Pembobot Spasial

Matriks pembobot spasial disimbolkan dengan $C$, jika $c_{i j}=1$ maka lokasi $i$ bertetangga dengan lokasi $j$, sedangkan $c_{i j}=0$ maka lokasi $i$ tidak bertetangga dengan lokasi $j$. ada juga matriks pembobot spasial terstandardisasi $(W)$ diperoleh dengan cara menbagi setiap elemen $C$ dengan jumlah masing-masing baris sehingga jumlah masingmasing baris adalah 1 (standarisasi baris) [7].

$$
w_{i j}=\frac{C_{i j}}{\sum_{j} C_{i j}} \text {. }
$$

\section{Autokorelasi Spasial}

Uji autokorelasi spasial bertujuan untuk memeriksa apakah nilai yang diamati dari variabel satu lokasi bergantung pada nilai variabel di lokasi yang berdekatan/bertetangga [4]. Autokorelasi spasial dapat diukur dengan dua cara yaitu autokorelasi spasial global dan autokorelasi spasial lokal, unutk menguji autokorelasi spasial global menggunakan indeks Moran $I$, indeks Geary $C$ dan Getis Ord, sedangkan untuk uji autokrelasi spasial lokal menggunakan Local Indicators of Spatial Association (LISA) [2].

Penelitian ini dibatasi pada pengujian autokorelasi spasial menggunakan indeks Geary $C$, yang dirumuskan sebagai berikut [4]:

$$
C_{G}=\frac{(n-1) \sum_{i=1}^{n} \sum_{j=1}^{n} w_{i j}\left(x_{i}-x_{j}\right)^{2}}{2\left(\sum_{i=1}^{n} \sum_{j=1}^{n} w_{i j}\right) \sum_{i=1}^{n}\left(x_{i}-\bar{x}\right)^{2}} .
$$

dengan

$C_{G} \quad=$ nilai indeks Geary $C$,

$n \quad=$ banyak lokasi pengamatan,

$x_{i} \quad=$ nilai pada lokasi $i$,

$x_{j} \quad=$ nilai pada lokasi $j$,

$w_{i j} \quad=$ elemen matriks pembobot spasial terstandarisasi.

dan nilai $0<C_{G}<2$ jika :

$0 \leq C_{G}<1=$ autokorelasi spasial positif,

$1<C_{G} \leq 2=$ autokorelasi spasial negatif.

Autokorelasi spasial positif menunjukkan bahwa nilai lokasi pengamatan tidak jauh berbeda dengan nilai 
tetangganya dan cenderung berkelompok. Sedangkan autokorelasi spasial negatif menunjukkan bahwa nilai lokasi pengamatan berbeda dengan nilai tetangganya dan cenderung menyebar.

Uji signifikansi indeks Geary $C$ dilakukan dengan pendekatan normal sebagai berikut [5].

1. Hipotesis:

$H_{0}: C_{G}=1$ (tidak terdapat autokorelasi spasial),

$H_{1}: C_{G} \neq 1$ (terdapat autokorelasi spasial).

2. Tingkat Signifikansi $(\alpha)$ :

3. Statistik Uji:

$$
\begin{gathered}
Z\left(C_{G}\right)=\frac{C_{G}-1}{\sqrt{v\left(C_{G}\right)}} \sim N(0,1) . \\
E\left(C_{G}\right)=1 . \\
v\left(C_{G}\right)=\frac{\left(2 S_{1}+S_{2}\right)(n-1)-4 S_{0}{ }^{2}}{2(n+1) S_{0}{ }^{2}},
\end{gathered}
$$

dengan

$$
\begin{aligned}
& S_{0}=\sum_{i=1}^{n} \sum_{j=1}^{n} w_{i j}, S_{1}=\frac{1}{2} \sum_{i \neq j}\left(w_{i j}+w_{j i}\right)^{2}, \\
& S_{2}=\sum_{k}\left(\sum_{j} w_{k j}+\sum_{i} w_{i k}\right)^{2} . \\
& \text { 4. Daerah Kritis: }
\end{aligned}
$$

Jika digunakan uji dua arah, untuk $\left|Z\left(C_{G}\right)\right|>Z_{(1-\alpha / 2)}$ atau nilai- $p<\alpha$ maka $H_{0}$ ditolak.

5. Kesimpulan: Pengambilan kesimpulan apakah $H_{0}$ diterima atau ditolak dan interpretasinya.

\section{Normal (Gaussian)}

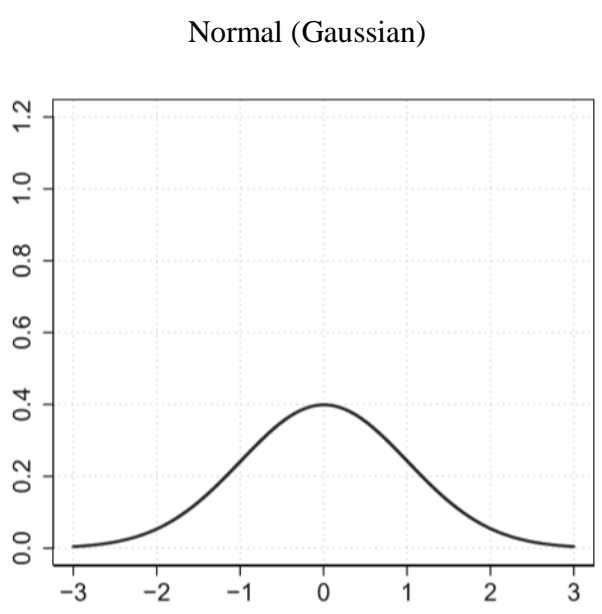

\section{Estimasi Densitas Kernel Univariat}

Misalnya terdapat sampel acak berukuran $n$ yaitu $X_{l}$, $X_{2}, \ldots, X_{n}$ yang berasal dari fungsi densitas $f$ yang tidak diketahui, maka estimasi fungsi densitas kernel dirumuskan sebagai berikut [8].

$$
\hat{f}(x, h)=\frac{1}{n h} \sum_{i=1}^{n} K\left(\frac{x-X_{i}}{h}\right) .
$$

dengan

$$
\begin{array}{ll}
n & =\text { jumlah sampel, } \\
h & =\text { bandwidth optimal, } \\
K & =\text { fungsi kernel. }
\end{array}
$$

Beberapa fungsi dan bentuk kernel yang biasa digunakan ditunjukkan pada Tabel I dan Gambar 2 [8].

TABEL I

FUNGSI KERNEL

\begin{tabular}{|l|l|}
\hline Nama Kernel & \multicolumn{1}{|c|}{$\boldsymbol{K ( x )}$} \\
\hline Normal (Gaussian) & $(2 \pi)(-1 / 2) \exp \left(\frac{x^{2}}{2}\right)$ \\
\hline Epanechnikov & $\left(\frac{3}{4}\right)\left(1-x^{2}\right)$ untuk $|x|<1$ \\
\hline Uniform (Box) & $\frac{1}{2}$ untuk $|x|<1$ \\
\hline Biweight & $\frac{15}{16}\left(1-x^{2}\right)^{2}$ untuk $|x|<1$ \\
\hline Triweight & $\frac{35}{32}\left(1-x^{2}\right)^{3}$ untuk $|x|<1$ \\
\hline Triangular & $(1-|x|)$ untuk $|x|<1$ \\
\hline
\end{tabular}

Epanechnikov

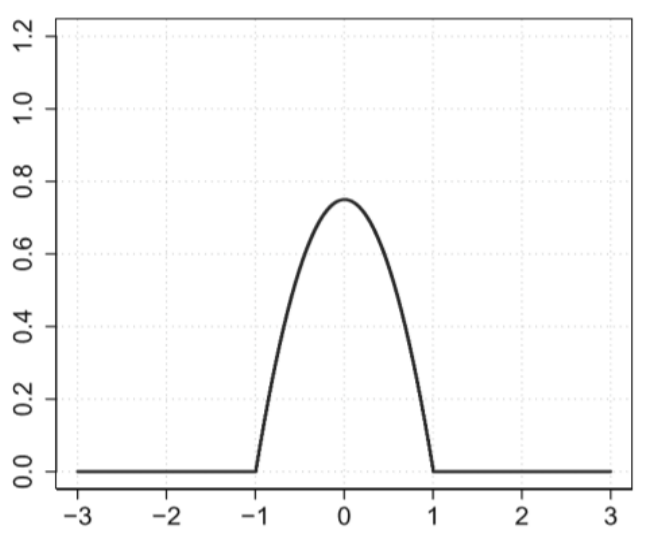



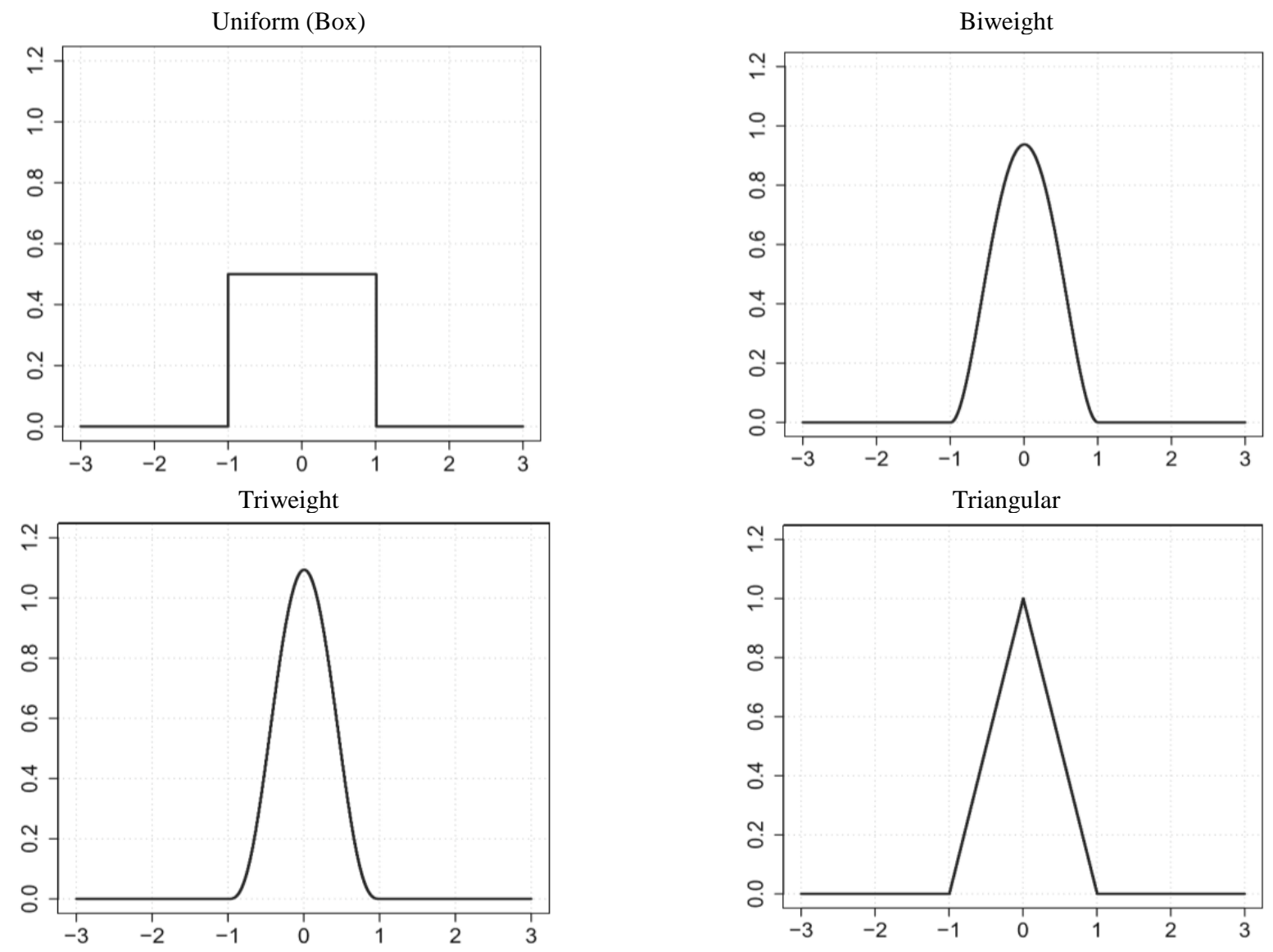

Gambar 2b. Bentuk fungsi kernel uniform (box), biweight, triweight dan triangular

Bandwidth $h$ merupakan bilangan positif, banyak kasus digunakan kernel normal [8]. bandwidth $h$ merupakan standar deviasi $(\sigma)$ pada distribusi normal seperti berikut

$$
N(x ; \mu, \sigma)=\frac{1}{\sqrt{2 \pi}} \exp \left(-\frac{\left(x-X_{i}\right)}{2 h^{2}}\right) .
$$

karena $K$ merupakan kernel berdistribusi normal baku $N(0,1)$ yang dituliskan seperti berikut

$$
K\left(\frac{x-X_{i}}{h}\right)=\frac{1}{\sqrt{2 \pi}} \exp \left(-\frac{\left(x-X_{i}\right)^{2}}{2 h^{2}}\right),
$$

Jadi berdasarkan persamaan (6) dan persamaan (8) maka estimasi densitas kernel dengan menggunakan fungsi kernel normal (gaussian) dirumuskan seperti berikut

$$
\hat{f}(x, h)=\frac{1}{n h} \sum_{i=1}^{n} \frac{1}{\sqrt{2 \pi}}\left(-\frac{\left(x-X_{i}\right)^{2}}{2 h^{2}}\right) .
$$

Pemilihan bandwidth $h$ optimal jika digunakan fungsi kernel normal (gaussian) dihitung menggunakan persamaan (10) [9]

$$
h_{\text {opt }}=\left(\frac{4}{3 n}\right)^{1 / 5} \sigma \text {. }
$$

dengan $\sigma$ adalah standar deviasi dari data.
Selanjutnya dilakukan resampling berdasarkan estimasi densitas kernel, berikut ini prosedur menghitung indeks Geary $C$ menggunakan resampling berdasarkan estimasi densitas kernel sebagai berikut [10]:

1. Dimiliki sampel univariat dengan ukuran $n$ yaitu $X_{l}$, $X_{2}, \ldots, X_{n}$.

2. Gunakan bandwidth optimal berdasarkan persamaan (10) untuk menghitung densitas kernel univariat berdasarkan sampel $X_{l}, X_{2}, \ldots, X_{n}$.

3. Sampel $X_{i}{ }^{*}=\left(x_{i 1}{ }^{*}, x_{i 2}{ }^{*}, \ldots, x_{i n}{ }^{*}\right)^{T}$ disekitaran $X_{i}$ (yang dipilih secara acak dari $X_{l}, X_{2}, \ldots, X_{n}$ ) dengan cara membangkitkan sampel yang berukuran 1 dari distribusi normal univariat dengan rata-rata $X_{i}$ dan variansinya yaitu bandwidth $h$ optimal $\left(h_{\text {opt }}\right)$.

4. Sampel baru $X_{i}{ }^{*}$ digunakan untuk menghitung nilai indeks Geary $C$, dengan $G_{i}=G\left(X_{i}\right)$ untuk $i=1,2, \ldots, B$ dan $B$ dipilih bebas (bilangan besar non-negatif).

5. Indeks Geary $C$ yang diperoleh sebanyak $B$ yaitu $G_{1}, G_{2}$, $G_{B}$.

Setelah diperoleh fungsi densitas indeks Geary $C$ berdasarkan resampling estimasi densitas kernel, selanjutnya dicari nilai- $p$ untuk menentukan apakah hipotesi nol $\left(H_{0}\right)$ diterima atau tidak. Nilai- $p$ dihitung sebagai berikut [10]. 


$$
\text { nilai- } p=2 \cdot\left(1-\frac{\#\left(G_{i}>C_{G}\right)}{B}\right) .
$$

dengan

$G_{i}=$ indeks Geary $C$ berdasarkan resampling estimasi densitas kernel, dengan $i=1,2, B$.

$C_{G}=$ indeks Geary $C$.

\section{METOde PENELITIAN}

\section{A. Sumber Data dan Data}

Data yang digunakan dalam penelitian ini merupakan data sekunder yang diperoleh dari website Badan Pusat Statistik [11], data yang digunakan yaitu data Indeks Pembangunan Manusia (IPM) Kabupaten/Kota di Provinsi Maluku Utara tahun 2013-2017.
B. Prosedur Analisis Data

Berikut ini langkah-langkah dalam menganalisis data

1. Data indeks pembangunan manusia (IPM) Kabupaten/Kota di Provinsi Maluku Utara tahun 2013 sampai 2017.

2. Membuat matriks pembobot spasial dengan cara menentukan ketetanggan antar Kabupaten/Kota berdasarkan peta Provinsi Maluku Utara.

3. Menghitung indeks Geary $C$ berdasarkan rumus pada persamaan (2).

4. Menentukan fungsi densitas kernel dari data pada point 1 berdasarkan persamaan (9).

5. Membangkitkan data baru untuk menghitung indeks Geary $C$ menggunakan resampling berdasarkan estimasi densitas kernel.

6. Kesimpulan.

Data Indeks Pembangunan Manusia (IPM) Kabupaten/Kota di Provinsi Maluku Utara tahun 2013-2017 disajikan pada Tabel II.

TABEL II

Indeks Pembangunan Manusia (IPM) KabUPaten/Kota di Provinsi Maluku UtaRa Tahun 2013-2017

\begin{tabular}{|l|l|c|c|c|c|c|}
\hline No & \multicolumn{1}{|c|}{ Kabupaten/Kota } & $\mathbf{2 0 1 3}$ & $\mathbf{2 0 1 4}$ & $\mathbf{2 0 1 5}$ & $\mathbf{2 0 1 6}$ & \multicolumn{1}{|c|}{$\mathbf{2 0 1 7}$} \\
\hline 1 & Kabupaten Halmahera Barat & 61,47 & 62,06 & 62,97 & 63,83 & 64,19 \\
\hline 2 & Kabupaten Halmahera Tengah & 60,89 & 61,49 & 62,07 & 63,05 & 63,89 \\
\hline 3 & Kabupaten Kepulauan Sula & 59,77 & 60,18 & 60,50 & 61,25 & 62,04 \\
\hline 4 & Kabupaten Halmahera Selatan & 59,92 & 60,34 & 61,26 & 62,17 & 62,64 \\
\hline 5 & Kabupaten Halmahera Utara & 63,81 & 64,18 & 65,04 & 66,02 & 66,52 \\
\hline 6 & Kabupaten Halmahera Timur & 62,71 & 63,26 & 63,99 & 64,92 & 65,77 \\
\hline 7 & Kabupaten Pulau Morotai & 57,97 & 58,34 & 59,27 & 59,87 & 60,71 \\
\hline 8 & Kabupaten Pulau Taliabu & 56,86 & 57,31 & 58,26 & 58,66 & 59,03 \\
\hline 9 & Kota Ternate & 76,69 & 77,15 & 77,64 & 77,80 & 78,48 \\
\hline 10 & Kota Tidore Kepulauan & 66,25 & 66,76 & 67,45 & 68,37 & 69,25 \\
\hline
\end{tabular}




\section{HASIL DAN PEMBAHASAN}

Statistik deskriptif menjelaskan karakteristik dari data, sehingga memudahkan dalam membaca dan memahami data tersebut. Statistik deskriptif data IPM Kabupaten/Kota di Provinsi Maluku Utara tahun 2013-2017 disajikan pada Tabel III. berdasarkan Tabel III terlihat bahwa tahun 2013 sampai 2017 IPM terendah terdapat di Kabupaten Pulau Taliabu, sedangkan pada tahun yang sama IPM tertinggi terdapat di Kota Ternate. Akan tetapi, tahun 2013 sampai 2017 IPM terendah maupun tertinggi mengalami kenaikan.

TABEL III

STATISTIK DESKRIPTIF IPM KABUPATEN/KOTA di PROVInSI MALUKu UTARA

\begin{tabular}{|l|c|c|c|c|c|}
\hline $\begin{array}{l}\text { Statistik } \\
\text { Deskriptif }\end{array}$ & $\mathbf{2 0 1 3}$ & $\mathbf{2 0 1 4}$ & $\mathbf{2 0 1 5}$ & $\mathbf{2 0 1 6}$ & $\mathbf{2 0 1 7}$ \\
\hline Minimum & 56,860 & 57,310 & 58,260 & 58,660 & 59,030 \\
\hline Maksimum & 76,690 & 77,150 & 77,640 & 77,800 & 78,480 \\
\hline Mean & 62,634 & 63,107 & 63,845 & 64,594 & 65,252 \\
\hline Median & 61,180 & 61,775 & 62,520 & 63,440 & 64,040 \\
\hline Variansi & 31,899 & 31,999 & 30,962 & 29,816 & 30,256 \\
\hline Kuartil 1 & 59,807 & 60,220 & 60,690 & 61,480 & 62,190 \\
\hline Kuartil 3 & 63,535 & 63,950 & 64,777 & 65,745 & 66,332 \\
\hline
\end{tabular}

\section{A. Hipotesis Uji}

Hipotesis uji digunakan untuk membantu dalam penarikan kesimpulan dari hasil indeks Geary $C$ berdasarkan pendekatan normal dan indeks Geary $C$ menggunakan resampling berdasarkan estimasi densitas kernel.

$H_{0}: C_{G}=1$ (tidak terdapat autokorelasi spasial pada indeks pembangunan manusia (IPM) di Provinsi Maluku Utara tahun $i$ ),

$H_{1}: C_{G} \neq 1$ (terdapat autokorelasi spasial pada indeks pembangunan manusia (IPM) di Provinsi Maluku Utara tahun $i$ ),

dengan $i=2013,2014,2015,2016,2017$.

Nilai $C_{G}$ berada diantara 0 sampai 2, dengan digunakan statistik uji pada persamaan (3). Kriteria keputusan jika $\left|Z\left(C_{G}\right)\right|>Z_{(1-\alpha / 2)}$ atau nilai- $p<\alpha$ maka $H_{0}$ ditolak.

\section{B. Analisis Menggunakan Indeks Geary C}

Perhitungan indeks Geary $C$ berdasarkan pendekatan normal dilakukan seperti penjelasan di Bab II untuk menentukan apakah terdapat autokorelasi spasial pada IPM Kabupaten/Kota di Provinsi Maluku Utara. Algoritma perhitungan nilai- $p$ indeks Geary $C$ dihitung menggunakan program R.3.5.1 disajikan pada Gambar 13 (Lampiran) dan hasil perhitungan disajikan pada Tabel IV.
TABEL IV

Hasil ANALISIS MENGGUNAKAN INDEKS GEARY $C$

\begin{tabular}{|l|l|l|l|}
\hline Tahun & \multicolumn{1}{|c|}{$\boldsymbol{C}_{\boldsymbol{G}}$} & $\left|Z\left(C_{G}\right)\right|$ & Nilai- $\boldsymbol{p}$ \\
\hline 2013 & 0,3987 & 2,0566 & 0,0397 \\
\hline 2014 & 0,3941 & 2,0725 & 0,0382 \\
\hline 2015 & 0,3822 & 2,1132 & 0,0346 \\
\hline 2016 & 0,3834 & 2,1092 & 0,0349 \\
\hline 2017 & 0,3841 & 2,1064 & 0,0352 \\
\hline
\end{tabular}

Digunakan tingkat signifikansi $\alpha=5 \%$ dan dengan bantuan program R.3.5.1 diperoleh nilai $Z_{(1-\alpha / 2)}=1,96$.

Berdasarkan hasil pada Tabel IV, dapat dilihat bahwa dari tahun 2013 sampai dengan 2017 hasil $\left|Z\left(C_{G}\right)\right|$ lebih besar dari $Z_{(1-\alpha / 2)}$ yang berarti bahwa $H_{0}$ ditolak, atau bisa juga dilihat dari nilai- $p$. Karena nilai $p$ dari tahun 2013 sampai dengan 2017 lebih kecil dari $\alpha=0,05$ maka $H_{0}$ ditolak artinya terdapat autokorelasi spasial pada indeks pembangunan manusia (IPM) Kabupaten/Kota di Provinsi Maluku Utara tahun 2013 sampai dengan 2017. Terdapat autokorelasi spasial berarti bahwa terdapat keterkaitan pada indeks pembangunan manusia (IPM) antar Kabupaten/Kota yang bertetangga, sebagai contoh IPM pada Kabupaten Halmahera Utara tinggi maka akan mempengaruhi IPM Kabupaten Halmahera Barat (bertetangga) juga tinggi.

Indeks Geary $C$ pada tahun 2013 sampai dengan 2017 berada antara 0 sampai 1 maka merupakan autokorelasi spasial positif artinya Kabupaten/Kota yang bertetangga memiliki IPM yang tidak jauh berbeda dan cenderung berkelompok. Sebagai contoh, ditahun 2017 IPM Kabupaten Halmahera Timur adalah 65,77 tidak jauh beda dengan IPM Kabupaten Halmahera Tengah yaitu 63,89 (Kabupaten Halmahera Timur bertetangga dengan Kabupaten Halmahera Tengah) [11].

\section{Analisis Estimasi Densitas Kernel Univariat}

Untuk menghitung estimasi densitas kernel pertamatama dihitung bandwith optimal $\left(h_{\text {opt }}\right)$. berdasarkan persamaan (10) maka diperoleh $h_{\text {opt }}$ dari IPM Kabupaten/Kota di Provinsi Maluku Utara tahun 2013-2017 yaitu $h_{1}=3,775, h_{2}=3,781, h_{3}=3,719, h_{4}=3,649$ dan $h_{5}=3,649$.

Selanjutnya digunakan persamaan (9) dan dipilih $x$ dari 52 sampai 82 dengan jarak 0,1 untuk melihat bentuk dari fungsi estimasi densitas kernel pada IPM Kabupaten/Kota di Provinsi Maluku Utara tahun 2013-2017, dengan bantuan program R.3.5.1 diperoleh bentuk estimasi densitas kernel pada masing-masing tahun disajikan pada Gambar 3 sampai Gambar 7. 


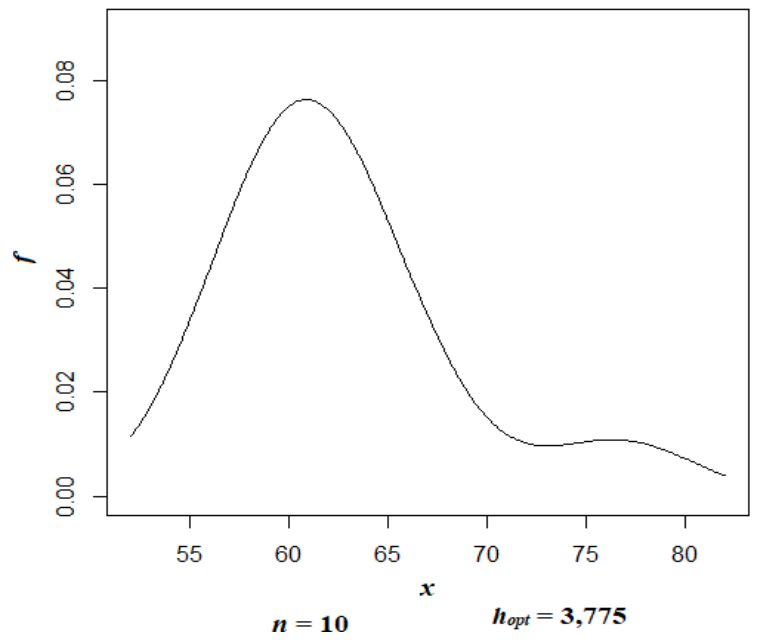

Gambar 3. Estimasi densitas kernel tahun 2013

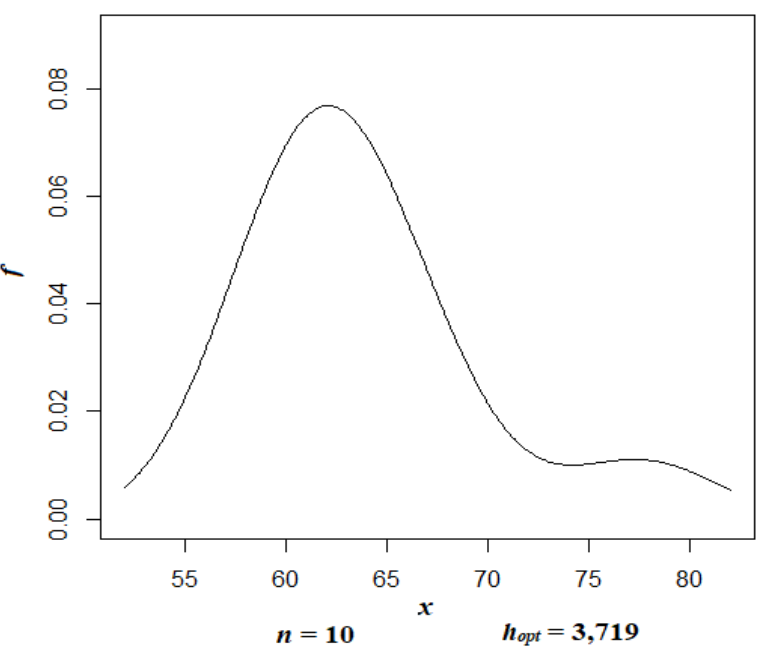

Gambar 5. Estimasi densitas kernel tahun 2015

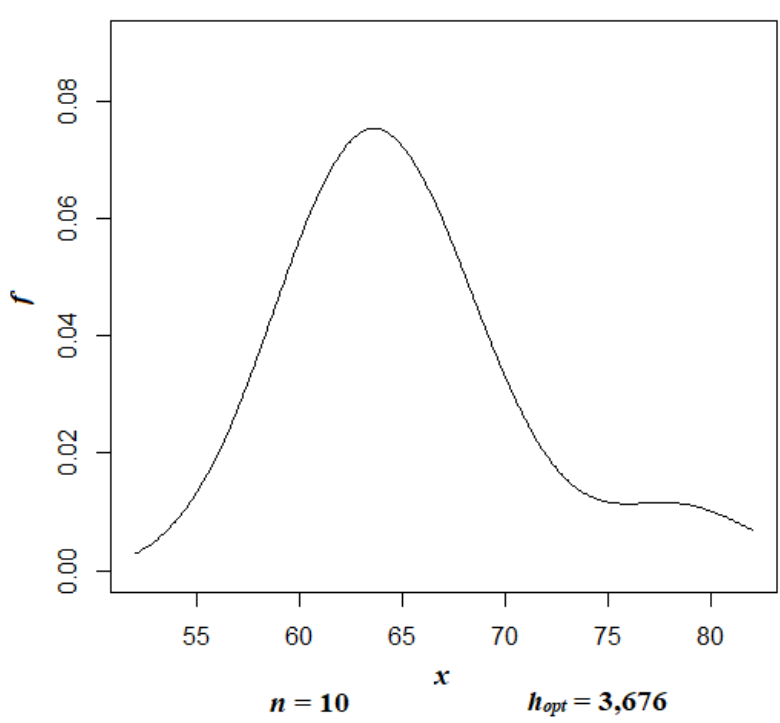

Gambar 7. Estimasi densitas kernel tahun 2017

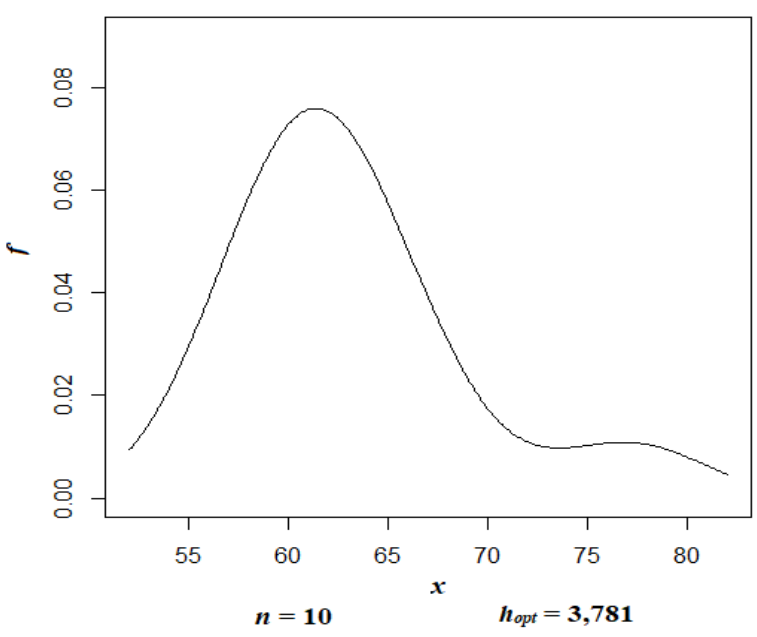

Gambar 4. Estimasi densitas kernel tahun 2014

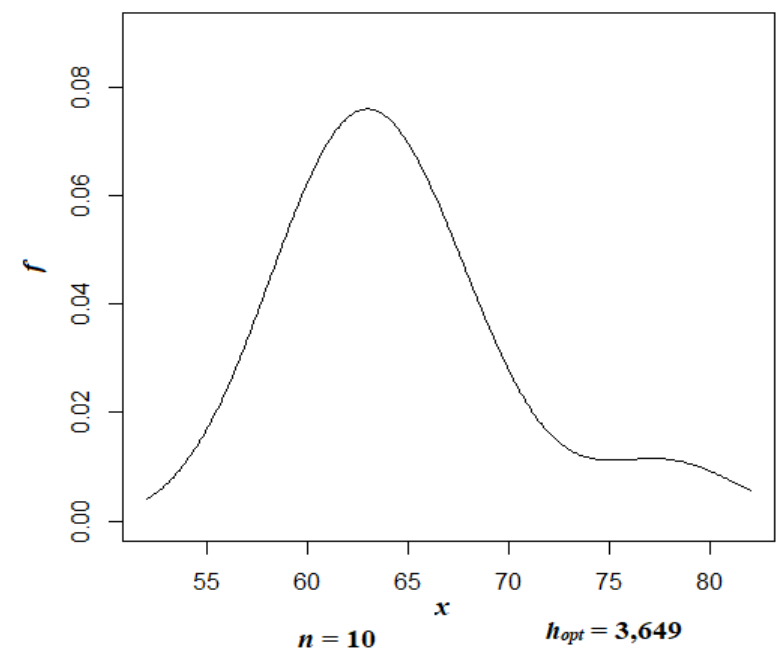

Gambar 6. Estimasi densitas kernel tahun 2016

Gambar 3 sampai Gambar 7 merupakan bentuk dari estimasi densitas kernel dari indeks pembangunan manusia (IPM) di Provinsi Maluku Utara tahun 2013 sampai 2017, dengan digunakan nilai $h_{\text {opt }}$ yang berbeda-beda namun selisih nilai $h_{\text {opt }}$ yang tidak berbeda jauh maka bentuk dari estimasi densitas kernel terlihat mirip.

\section{Resampling Berdasarkan Estimasi Densitas Kernel}

Hasil perhitungan indeks Geary $C$ dengan pendekatan normal sudah ditunjukkan pada Tabel IV, dengan hasilnya menyatakan bahwa dari tahun 2013 sampai dengan 2017 terdapat Autokorelasi Spasial pada IPM Kabupaten/Kota di Maluku Utara. Selanjutnya akan dilakukan uji autokorelasi spasial dengan indeks Geary $C$ menggunakan Resampling berdasarkan Estimasi Densitas Kernel (Univariat) untuk mencari fungsi distribusi statistik Geary $C$ kemudian menarik kesimpulan dari hasil yang diperoleh.

Digunakan bandwidth optimal $\left(h_{\text {opt }}\right)$ seperti pada SubBab sebelumnya, kemudian dilakukan pengambilan sampel sebanyak satu sampel dari tiap-tiap IPM. Kemudian dari 
sampel yang diperoleh dibangkitkan data baru sebanyak satu data dari persekitaran sepuluh sampel yang terambil (terdapat 10 kabupaten/kota) selanjutnya dihitung nilai indeks Geary $C$. Setelah dilakukan pengulangan sebanyak 10000 kali pengambilan sampel baru diperoleh hasil density Geary $C$ seperti pada Gambar 8 sampai Gambar 12.

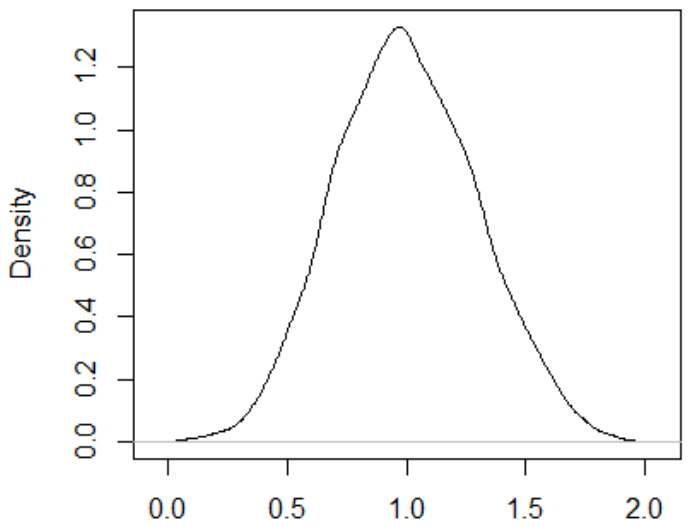

Gambar 8. Estimasi densitas kernel indeks geary c untuk IPM tahun 2013 hasil resampling berdasarkan estimasi densitas kernel

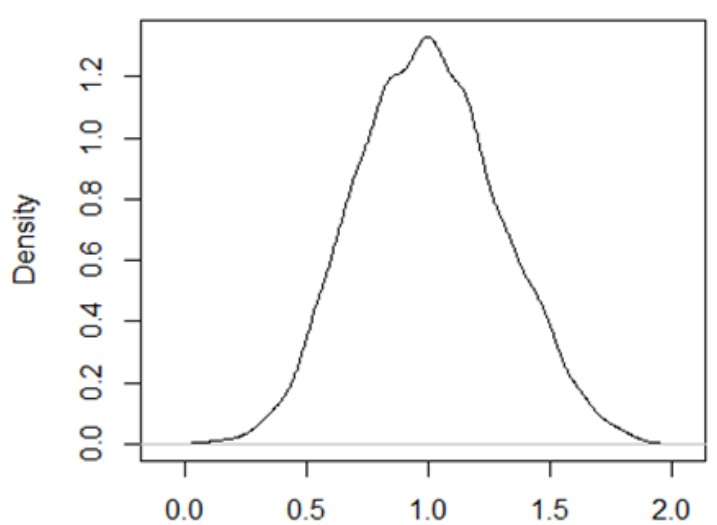

Gambar 9. Estimasi densitas kernel indeks geary $c$ tahun 2014 hasil resampling berdasarkan estimasi densitas kernel

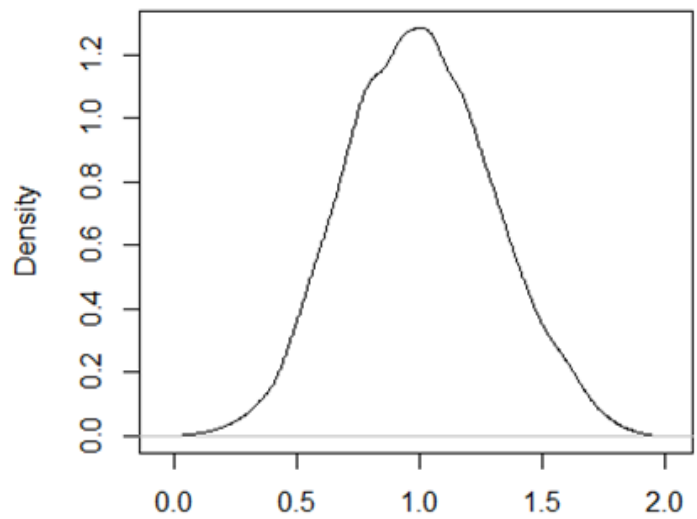

Gambar 10. Estimasi densitas kernel indeks geary $c$ untuk IPM tahun 2015 hasil resampling berdasarkan estimasi densitas kernel

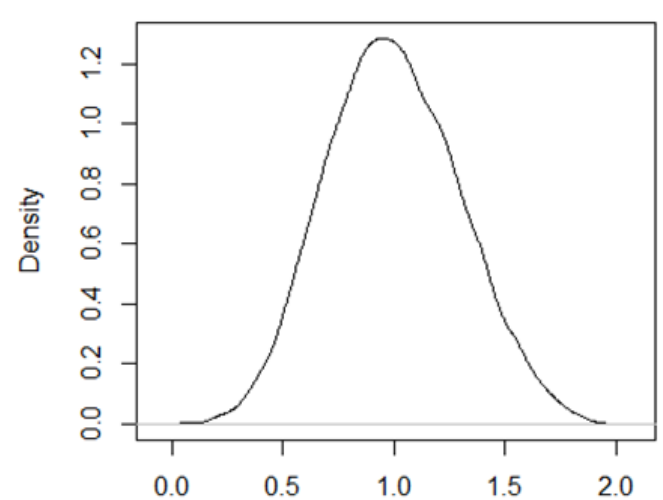

Gambar 11. Estimasi densitas kernel indeks geary $c$ untuk IPM tahun 2016 hasil resampling berdasarkan estimasi densitas kernel

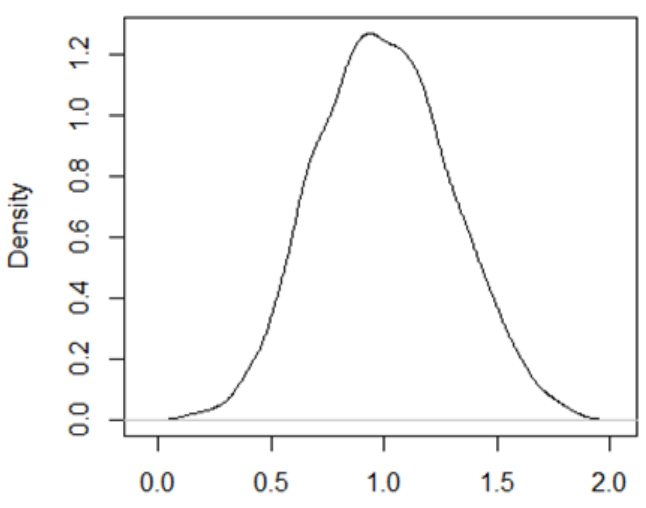

Gambar 12. Estimasi densitas kernel indeks geary $c$ untuk IPM tahun 2017 hasil resampling berdasarkan estimasi densitas kernel 
Hasil densitas indeks Geary $C$ berdasarkan Estimasi Densitas Kernel setelah dilakukan penggulangan 10000 kali, dengan $h_{\text {opt }}$ yang disajikan pada Gambar 8 sampai dengan Gambar 12, selanjutnya fungsi distribusi tersebut dicari nilai- $p$ untuk mengecek hipotesis awal $\left(\mathrm{H}_{0}\right)$ terima atau ditolak.

Uji Kolmogorov Smirnov (ks.test) digunakan untuk menentukan apakah densitas indeks Geary $C$ hasil resampling berdasarkan estimasi densitas kernel dengan 10000 kali penggulangan berdistribusi normal atau tidak. Jika nilai- $p$ dari uji ks.test kurang dari signifikansi $(\alpha)$ maka statistik Geary $C$ tidak berdistribusi normal. Algoritma perhitungan nilai- $p$ indeks Geary $C$ berdasarkan resampling estimasi densitas kernel menggunakan program R.3.5.1 disajikan pada Gambar 14 (Lampiran) dan hasil nilai-p indeks Geary $C$ menggunakan resampling berdasarkan estimasi densitas kernel dan nilai- $p$ hasil uji Kolmogorov Smirnov (ks.test) disajikan pada Tabel V.

TABEL V

NILAI- $P$ HASIL INDEKS GEARY $C$ BERDASARKAN RESAMPLING ESTIMASI DENSITAS KERNEL dan UJI KOLMOGOROV SMIRNOV (ks.test)

\begin{tabular}{|l|l|l|}
\hline Tahun & $\begin{array}{c}\text { Nilai-p hasil indeks Geary } \boldsymbol{C} \\
\text { berdasarkan resampling } \\
\text { estimasi densitas kernel }\end{array}$ & $\begin{array}{c}\text { Nilai-p } \\
\text { hasil } \boldsymbol{k s . t e s t}\end{array}$ \\
\hline 2013 & 0,0318 & 0,0196 \\
\hline 2014 & 0,0272 & 0,0044 \\
\hline 2015 & 0,0282 & 0,0269 \\
\hline 2016 & 0,0262 & 0,0094 \\
\hline 2017 & 0,0258 & 0,0295 \\
\hline
\end{tabular}

Berdasarkan Tabel V, nilai- $p$ hasil indeks Geary $C$ menggunakan resampling berdasarkan estimasi densitas kernel untuk IPM 2013 sampai dengan 2017 berturut-turut adalah 0,0318, 0,0272, 0,0282, 0,0262 dan 0,0258 kurang dari $\alpha=0,05$ maka $\mathrm{H}_{0}$ ditolak, artinya terdapat autokorelasi spasial pada IPM Kabupaten/Kota di Provinsi Maluku Utara tahun 2013 sampai dengan 2017 dengan kata lain bahwa dari tahun 2013 sampai dengan tahun 2017 IPM Kabupaten/Kota akan mempengaruhi IPM Kabupaten/Kota yang bertetanga. Misalnya IPM Kabupaten Halmahera Utara tinggi maka IPM Kabupaten Halmahera Barat (bertetangga) juga cenderung tinggi, hal tersebut dibuktikan pada tahun 2017 IPM Kabupaten Halmahera Utara yaitu 66,52 sedangkan ditahun yang sama IPM Kabupaten Halmahera Barat yaitu 64,19 (IPM tidak berbeda jauh) karena kedua Kabupaten bertetangga dan memiliki hubungan spasial secara global (indeks Geary $C$ merupakan uji autokorelasi spasial global). Hal yang sama berlaku untuk Kabupaten/Kota lain yang saling bertetanggaan.

Meskipun Gambar 8 sampai dengan 12 terlihat mengikuti bentuk distribusi normal, tetapi setelah dilakukan uji Kolmogorov Smirnov diperoleh nilai- $p$ yaitu 0,0196, 0,0044, 0,0269, 0,0094 dan 0,0295 kurang dari $\alpha=0,05$ maka statistik Geary $C$ tidak berdistribusi normal.
Berdasarkan uji Kolmogorov Smirnov, IPM Kabupaten/Kota di Provinsi Maluku Utara tahun 2013-2017 diperoleh indeks Geary $C$ tidak berdistribusi normal maka dalam uji autokorelasi spasial dengan indeks Geary $C$ tidak dapat digunakan dengan pendekatan normal.

\section{KESIMPULAN}

Berdasarkan hasil dan pembahasan didapatkan, nilai indeks Geary $C$ berdasarkan resampling estimasi densitas kernel menunjukkan bahwa terdapat autokorelasi spasial pada Indeks Pembangunan Manusia (IPM) Kabupaten/Kota di Provinsi Maluku Utara tahun 2013-2017, artinya bahwa IPM Kabupaten/Kota yang satu akan mempengaruhi IPM Kabupaten/Kota lain yang bertetangga dengannya. Berdasarkan uji Kolmogorov Smirnov, statistik indeks Geary $C$ hasil resampling berdasarkan estimasi densitas kernel tidak berdistribusi normal artinya dalam uji autokorelasi spasial dengan indeks Geary $C$ pada data IPM Kabupaten/Kota di Provinsi Maluku Utara tahun 2013-2017 tidak dapat digunakan pendekatan normal.

\section{DAFTAR PUSTAKA}

[1] W. Weku, A. Setiawan, \& S. Yulianto, "Analisis Pola Spasial dan Dinamika IPM Tahun 2006-2009 Provinsi Sulawesi Utara Menggunakan Metode Spatial Autocorrelation," Prosiding Seminar Nasional Matematika yang diselenggarakan oleh Universitas Parahyangan, 2012.

[2] E. K. Nisa, "Identifikasi Spatial Pattern dan Spatial Autocorrelation pada Indeks Pembangunan Manusia Provinsi Papua Barat Tahun 2012," Jurnal At-Taqaddum, Vol 9, No. 2, pp. 202-226, Nov. 2017.

[3] Badan Pusat Statistik, Indeks Pembangunan Manusia 2014 Metode Baru, Jakarta : Badan Pusat Statistik, 2015.

[4] Y. M. Zhokov. (2010) Applied Spatial Statistics in R. [Online] Tersedia:

https://sites.lsa.umich.edu/zhukov/wp-

content/uploads/sites/140/2014/08/applied-spatial-stats.pdf

[5] N. Faiz, R. Rahmawati, \&D.Safitri, "Analisis Spasial Penyebaran Penyakit Demam Berdarah Dengue dengan Indeks Moran dan Geary's C (Studi Kasus di Kota Semarang Tahun 2011)," Jurnal Gaussian, Vol 2, No. 1, pp. 69-78, 2013.

[6] E. Sediyono \& A. Setiawan, Catatan Kuliah Tentang Fuzzy : Implementasi Metode Fuzzy untuk Analisis Pemanfaatan Lahan Kosong Menjadi Lahan Pangan di Wilayah Minahasa Tenggara, Salatiga : Satya Wacana University Press, 2015.

[7] Y. Chun \& D. A. Griffith, Spatial Statistic \& Geostatistics, Texas : University Of Texas, 2013.

[8] A. Gramacki, Nonparametric Kernel Density Estimation and Its Computational Aspect, Zielona Gora : Springer International Publishing, 2018.

[9] W. Zucchini. (2003) Applied Smoothing Techniques Part 1 : Kernel Density Estimation. [Online].Tersedia: http://www.staff.ustc.edu.cn/ Zwp/teach/Math-Stat/kernel.pdf

[10] A. Setiawan, "Resampling Berdasarkan Estimasi Densitas Kernel Bivariat," Prosiding Seminar Nasional Matematika VI Universitas Negeri Semarang, ISBN : 978-602-17495-0-0, 2012.

[11] Badan Pusat Statistik. (2018) Tabel Indeks Pembangunan Manusia (Metode Baru). [Online].Tersedia:

http://www.ipm.bps.go.id/data/provinsi/metode/baru/8200. 
R RGui (64-bit)

File Edit View Misc Packages Windows Help

\section{圆圆回国圆家圆圆 \\ R R Console
$>\# \mathrm{H}$ opt \\ $>(\mathrm{h} \overline{1}=((4 /(3 * 10)) \wedge(1 / 5)) * \operatorname{sd}(\operatorname{IPM}[, 1]))$ \\ [1] 3.774653 \\ $>(\mathrm{h} 2=((4 /(3 * 10)) \wedge(1 / 5)) * \operatorname{Sd}(\operatorname{IPM}[, 2]))$ \\ [1] 3.780545 \\ $>(\mathrm{h} 3=((4 /(3 * 10)) \wedge(1 / 5)) * \operatorname{sd}(\operatorname{IPM}[, 3]))$ \\ [1] 3.718791 \\ $>(\mathrm{h} 4=((4 /(3 * 10)) \wedge(1 / 5)) * \operatorname{sd}(\operatorname{IPM}[, 4]))$ \\ [1] 3.649369 \\ $>(\operatorname{h} 5=((4 /(3 * 10)) \wedge(1 / 5)) * \operatorname{sd}(\operatorname{IPM}[, 5]))$ \\ [1] 3.676163}

\#resampling kde

$\mathrm{x}=\operatorname{IPM}[, 2]$

$\mathrm{n}=$ length $(\mathrm{x})$

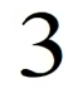

$\mathrm{h}=\mathrm{h} 2$

$\mathrm{B}=10000$

$\mathrm{G}=$ numeric $(\mathrm{B})$

$\mathrm{C}=$ geary $(\mathrm{x}, \mathrm{w})$

for ( $i$ in 1:B)

\{

$\mathrm{x} 1=$ numeric $(\mathrm{n})$

for $(j$ in $1: n)$

\{

$\mathrm{u}=\operatorname{sample}(\mathrm{x}, 1)$

$\mathrm{x} 1[\mathrm{j}]=\operatorname{rnorm}(1, \mathrm{u}, \mathrm{h})$

\}

$\mathrm{G}[\mathrm{i}]=\operatorname{geary}(\mathrm{x} 1, \mathrm{w})$

\}

plot (density (G), xlab=" ", main=" ")

$($ nilai.p $=2 *(1-\operatorname{sum}(G>C) / B))$

[1] 0.0272

\section{R R Console}

\#resampling kde

$\mathrm{x}=\mathrm{IPM}[, 4]$

$\mathrm{n}=$ length $(\mathrm{x})$

$\mathrm{h}=\mathrm{h} 4$

$\mathrm{B}=10000$

$\mathrm{G}=$ numeric $(\mathrm{B})$

$\mathrm{C}=$ geary $(\mathrm{x}, \mathrm{w})$

for ( $i$ in 1:B)

\{

$\mathrm{x} 1=$ numeric $(\mathrm{n})$

for $(j$ in $1: n)$

\{

$\mathrm{u}=\operatorname{sample}(\mathrm{x}, 1)$

$\mathrm{x} 1[\mathrm{j}]=\operatorname{rnorm}(1, \mathrm{u}, \mathrm{h})$

+ \}

+ $[i]=\operatorname{geary}(x 1, w)$

+ \}

plot (density $(G), x l a b="$ ", main=" ")

$>(\mathrm{nilai} \cdot \mathrm{p}=2 *(1-\operatorname{sum}(\mathrm{G}>\mathrm{C}) / \mathrm{B}))$

[1] 0.0262

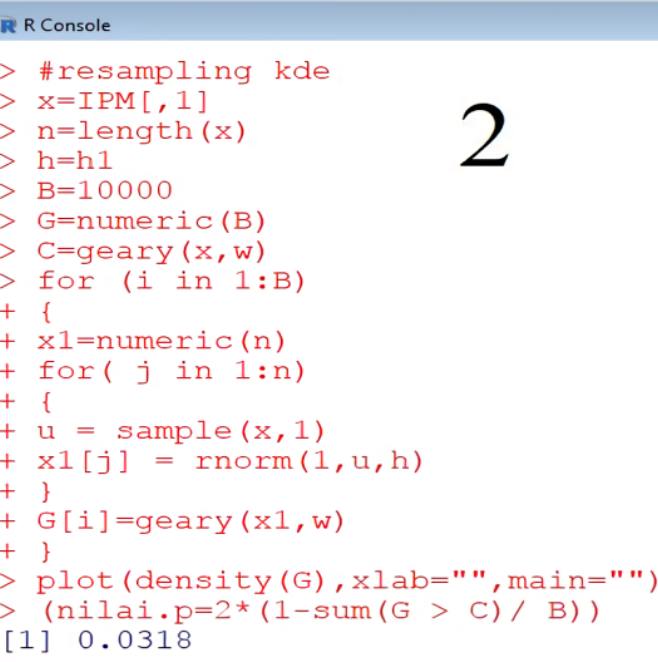

\section{R Console}

\#resampling kde

$\mathrm{x}=\operatorname{IPM}[, 3]$

$\mathrm{n}=$ length $(\mathrm{x})$

$\mathrm{h}=\mathrm{h} 3$

$\mathrm{B}=10000$

$\mathrm{G}=$ numeric (B)

$\mathrm{C}=\operatorname{geary}(\mathrm{x}, \mathrm{w})$

for ( $i$ in $1: B$ )

\{

$\mathrm{x} 1=$ numeric $(\mathrm{n})$

for $(j$ in $1: n)$

\{

$u=$ sample $(x, 1)$

$\mathrm{x} 1[\mathrm{j}]=\operatorname{rnorm}(1, \mathrm{u}, \mathrm{h})$

\}

$G[i]=\operatorname{geary}(\mathrm{x} 1, \mathrm{w})$

\}

plot (density $(G), x l a b="$ ", main=" ")

(nilai. $\mathrm{p}=2$ * $(1-\operatorname{sum}(\mathrm{G}>\mathrm{C}) / \mathrm{B}))$

[1] 0.0282

\section{R R Console}

$>$ \#resampling $\mathrm{kde}$

$>\mathrm{x}=\operatorname{IPM}[, 5]$

$>\mathrm{n}=$ length $(\mathrm{x})$

$>\mathrm{h}=\mathrm{h} 5$

$>\mathrm{B}=10000$

$>\mathrm{G}=$ numeric (B)

$>\mathrm{C}=\operatorname{geary}(\mathrm{x}, \mathrm{w})$

for ( $i$ in 1:B)

$+\{$

$+\mathrm{x} 1=$ numeric $(\mathrm{n})$

+ for $(j$ in 1:n)

$+\{$

$+\mathrm{u}=\operatorname{sample}(\mathrm{x}, 1)$

$+\mathrm{x} 1[\mathrm{j}]=\operatorname{rnorm}(1, \mathrm{u}, \mathrm{h})$

+ \}

$+\mathrm{G}[\mathrm{i}]=$ geary $(\mathrm{x} 1, \mathrm{w})$

+ \}

$>$ plot (density $(G), x l a b="$ ", main=" ")

$>(\mathrm{nilai} \cdot \mathrm{p}=2 *(1-\operatorname{sum}(\mathrm{G}>\mathrm{C}) / \mathrm{B}))$

[1] 0.0258

Gambar 14. Algoritma perhitungan nilai-p indeks gerary $c$ berdasarkan resampling estimasi densitas kernel menggunakan program $R . .3 .5 .1$ 